REFLECTIONS:

NEUROLOGY AND

THE HUMANITIES

Section Editor

Anne W. McCammon,

MD, FAAN

Nina Felice Schor, MD,

$\mathrm{PhD}$

Correspondence \& reprint requests to Dr. Schor: nina_schor@urmc.rochester.edu

\title{
On aging
}

\section{ME (MOTOR AND EMOTER)}

Once I had to ask the grown-ups what we wanted to do and why,

But then knew instantly how to do it.

Now I know what we want to do and why, But must ask the children how to do it.

I have always thought one gets only

So many synapses in a lifetime.

The young waste them all on

Memory motoric, while aging shifts them wisely to Philosophy limbic.

\section{US (SENSORY)}

Time was we ate Veg-All from a can

And folded back only half of the tin foil to expose The Salisbury steak (but not the peas)

In the days before microwave ovens.

Who would have thought that someday we'd eat fish only known to Food Network?

(What is barramundi anyway? And where did it swim when it lived?)

We recycle plastic and plug our cars into the wall.

We like our doctors rested, supported, socially welladjusted

With global and family sensibilities.

We no longer eat our young or throw them to the wolves.

We are learning, bit by bit, to find Kandahar, Tikrit, and Sana'a on the map,

To spell Peking with a "B" and Bombay with an "M."

Now in this well-past-adolescence of our lives,

We are hoping we begin to learn what it is to be human

And become.

\section{THEM (MEMORY)}

My life is divided into three places.

The place where I no longer know the names on the plaques on the wall,

The place where I still know the names on the plaques on the wall,

And the place where I do not yet know the names on the plaques on the wall.

The people in the middle place are my family of sorts.

We laughed, cried, celebrated, worried, and got angry together.

They left for good and then I did for a while.

But they and I left pieces behind, making the middle place somehow

Special for a moment.

In time, I will no longer know the names on the plaques on the wall

In the middle place. And the third place will become filled

With the names of my family

As the snapshot moves forward. 


\title{
Neurology
}

\author{
On aging \\ Nina Felice Schor \\ Neurology 2012;78;1188 \\ DOI 10.1212/WNL.0b013e31824f8114
}

\section{This information is current as of April 9, 2012}

\section{Updated Information \& Services}

Subspecialty Collections

Permissions \& Licensing

\section{Reprints}

including high resolution figures, can be found at: http://n.neurology.org/content/78/15/1188.full

This article, along with others on similar topics, appears in the following collection(s):

All Clinical Neurology

http://n.neurology.org/cgi/collection/all_clinical_neurology Cognitive aging

http://n.neurology.org/cgi/collection/cognitive_aging

Information about reproducing this article in parts (figures,tables) or in its entirety can be found online at:

http://www.neurology.org/about/about_the_journal\#permissions

Information about ordering reprints can be found online:

http://n.neurology.org/subscribers/advertise

Neurology ${ }^{\circledR}$ is the official journal of the American Academy of Neurology. Published continuously since 1951, it is now a weekly with 48 issues per year. Copyright Copyright (? 2012 by AAN Enterprises, Inc.. All rights reserved. Print ISSN: 0028-3878. Online ISSN: 1526-632X.

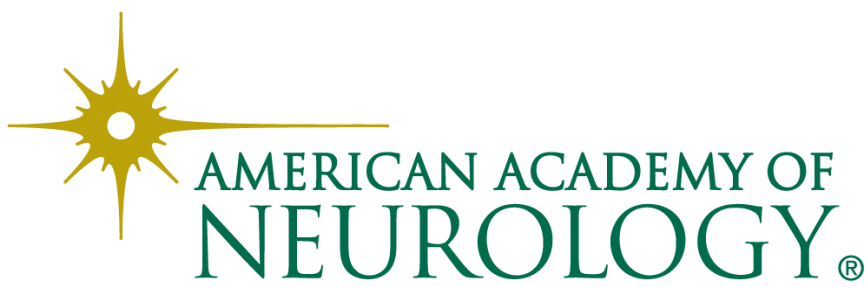

